
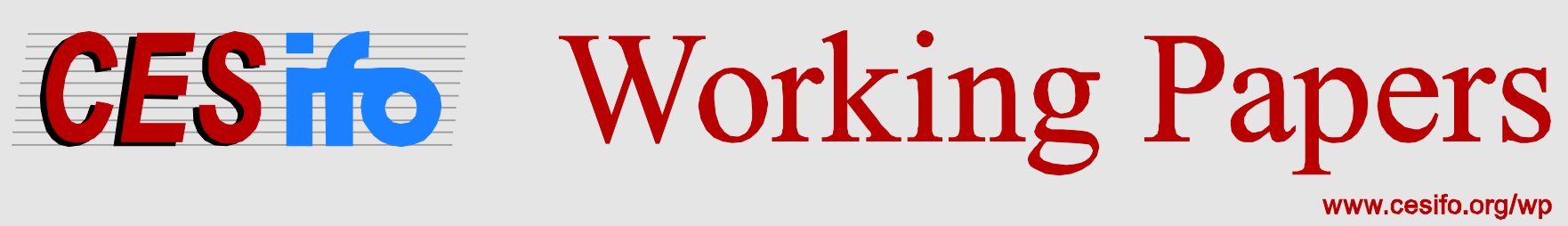

\title{
CFC Legislation, Passive Assets and the Impact of the ECJ's Cadbury-Schweppes Decision
}

\author{
Martin Ruf \\ Alfons J. Weichenrieder
}

CESIFO WORKING PAPER NO. 4461

CATEGORY 1: PUBLIC FinANCE

OCTOBER 2013

An electronic version of the paper may be downloaded

- from the SSRN website:

- from the RePEc website:

- from the CESifo website:

WWW.SSRN.com

www.RePEc.org

www.CESifo-group.org/wp

\section{CESifo}




\title{
CFC Legislation, Passive Assets and the Impact of the ECJ's Cadbury-Schweppes Decision
}

\begin{abstract}
In its Cadbury-Schweppes decision of 12 September 2006 (C-196/04), the Court of Justice of the European Union decided that the UK controlled foreign corporation rules, which were implemented to subject low taxed passive income of foreign affiliates to UK corporate tax, implied an infringement of the freedom of establishment. Consequently, many EU countries including Germany changed their legislation. The paper discusses to which extent the ECJ ruling has impacted on the allocation of passive assets in German multinationals. Using firm level data we find evidence for an increased preference for low-tax European countries compared to non-European countries.
\end{abstract}

JEL-Code: H250, H730.

Keywords: Court of Justice of the European Union, corporation tax, foreign direct investment, CFC regulation, passive investment.

\author{
Martin Ruf \\ Eberhard Karls University \\ Nauklerstraße 47 \\ Germany-72074 Tübingen \\ martin.ruf@uni-tuebingen.de
}

\author{
Alfons J. Weichenrieder \\ Goethe University \\ Faculty of Economics and Business \\ Administration \\ Germany - 60323 Frankfurt (Main) \\ a.weichenrieder@em.uni-frankfurt.de
}

16 October 2013

The hospitality and support of the Deutsche Bundesbank Research Center is gratefully acknowledged. Alfons Weichenrieder is also affiliated with the University of Economics and Business, Vienna, and with CESifo. 


\section{Introduction}

International corporate income tax differentials open up the potential for tax planning by multinational enterprises (MNEs). An important implication of tax differentials is that income of multinational firms that is earned by subsidiaries located in low-tax countries is usually treated preferentially compared to income earned by the parent corporation located in a high tax country. In cases where the home country of the parent uses an exemption system for taxing foreign profits neither the reinvested nor the repatriated profits of such a subsidiary are usually taxed by that home country and the lower tax rate on the subsidiary's profit becomes final. After recent tax changes in the UK and Japan, almost all major developed countries except the U.S. use exemptions systems like this. If the home country of the parent instead uses a credit system, repatriated profits will be taxed in the home country. While the low-tax advantage is then eliminated for distributed profits, reinvested profits may still enjoy a tax preference as home taxation is deferred until repatriation, which prefers an advantage of lowtax jurisdictions.

The tax preference that arises from the combination of a low tax rate abroad and an exemption of foreign profits in the parent's home country is usually accepted in cases where foreign low-tax affiliates actively compete with other businesses. At the same time, many home countries of multinationals have legislated special controlled foreign corporation (CFC) rules that apply if low-taxed affiliates try to exploit the exemption system of the parent country to invest in low-taxed passive assets abroad. Depending on country specific legislation, passive assets falling under CFC legislation may include holdings of bonds or portfolio equity, the ownership of acquired patent rights, and lending to other affiliated corporations.

CFC rules constitute an example of a unilateral measure that may secure the national tax base (Weichenrieder 1996). Such unilateral measures may form a substitute to multilateral measures, like tax rate coordination, that would also preserve countries' abilities to tax mobile 
capital. Against the background of aggressive tax avoidance by multinationals like Starbucks, Google and Amazon, the OECD (2013) has called for a strengthening of CFC rules by OECD member countries (action 3 of the OECD action plan on base erosion and profit shifting).

Whether unilateral action is working is essentially an empirical question. There are two previous studies that suggest a measureable impact of CFC rules on the decisions of MNEs that allocate passive assets. Altshuler and Hubbard (2003) analyze the Tax Reform Act of 1986 that changed the U.S. CFC rules (Subpart F provisions) and made it more difficult to defer home taxation of passive income abroad. The paper finds that the change in legislation reduced the tax sensitivity of the international location decisions of U.S. financial services firms, i.e., the attractiveness of low-tax countries, measured by the aggregated sum of financial assets received, was reduced by the tightening of the CFC rules. Ruf and Weichenrieder (2012) concentrate on non-financial subsidiaries of German firms and use micro data for the period 1996 to 2006 to test whether the applicability of the German CFC rules reduces the amount of passive assets in the respective countries. The study concludes that the amount of passive assets was significantly affected and that the magnitude of the effect was economically relevant. ${ }^{1}$

While the existing evidence on CFC-legislation gives support to the view that unilateral measures can help restricting the tax planning of MNEs, the existing evidence does not reflect a recent ruling of the Court of Justice of the European Union (ECJ). In its Cadbury-Schweppes decision of 12 September 2006 (C-196/04), the ECJ had to evaluate the case of a British MNE that had established two subsidiaries in Ireland. In 1996 one of these had received significant amounts of income from passive assets and the UK tax authorities in 2000 decided that based on British CFC rules a UK tax of GBP 8.6m had to be paid by the British parent. The case was referred to the ECJ by the UK court. The ECJ decided that the UK CFC rules implied discrimination and a restriction of the freedom of establishment. Had the UK parent set up a subsidiary in the UK (rather than in Ireland) then, the parent had not

\footnotetext{
${ }^{1}$ Egger and Wamser (2011) empirically discuss whether restrictions on passive investments have repercussions on the amount of active investment.
} 
been taxed on the income of the affiliate. However, this is what happened to the Irish subsidiary due to the UK CFC rules. The fact that the effective taxation of the Irish profits was not raised above the level that had evolved in the case of a UK subsidiary company did not change the view of the ECJ, as "the fact remains that under such legislation the resident company is taxed on profits of another legal person” (C-196/04, 45), a situation that had not occurred in the case of a national subsidiary. In the absence of overriding reasons of public interest, the ECJ held that the restriction cannot be justified by the Irish subsidiary taking advantage of the lower tax rate in Ireland. A restriction could only be justified to prevent the creation of a wholly artificial arrangement, which does not reflect economic reality, but a pure tax avoidance motive, as in the case of a pure letter box. Unless such a case can be proven, the ECJ decided that taxation based on CFC legislation is an infringement to the freedom of establishment. $^{2}$

The fact that the ruling was based on the freedom of establishment has important implications for the scope of the ECJ decision. The freedom of establishment is a right that is ceded to individuals and businesses located in the EU or the European Economic Area (EEA), but the respective article is not binding if a European company wants to locate a subsidiary outside the EU/EEA. ${ }^{3}$ Therefore European CFC rules may still discriminate against nonEuropean affiliates. Conversely, had the ECJ decision been explicitly based on the freedom of capital movements, a distinction between EEA and non-EEA countries was not possible.

In the literature, the discussion of the Cadbury-Schweppes ruling mainly centers about legal implications. On the economic side, it has been speculated that the ruling will increase the attractiveness of low-tax EU locations (Barry and Healy-Rae 2010), but many observers seem to hold the view that there is still sufficient uncertainty as to the extent to which the ECJ ruling gives protection from CFC rules, as the ECJ left the opportunity to counteract structures that are wholly artificial and solely due to tax reasons. Revisions of the CFC rules, as for example those in Germany, have taken advantage of this backdoor.

\footnotetext{
${ }^{2}$ See Treaty on the Functioning of the European Union, Articles 49 and 54 (ex 43 and 48 EC).

${ }^{3}$ The EEA includes the EU countries plus Liechtenstein, Norway and Iceland.
} 
The distinction between EEA and non-EEA countries opens up the possibility to empirically consider the differential effect that the ECJ decision had on passive assets that European multinationals located in the EEA and outside the EEA in a quasi-experimental setting. More specifically, the present paper looks at data of German multinationals to conclude whether the Cadbury-Schweppes decision had an impact on passive asset location. To our knowledge, this is the first effort to evaluate the empirical effect of this ECJ decision econometrically. ${ }^{4}$

The rest of the paper proceeds as follows. Section 2 will give a description of the German CFC rules and discusses the reaction in German legislation that was triggered by the ECJ decision. Section 3 introduces the data source and provides econometric evidence on the differential development of passive investment in EEA and non-EEA countries.

\section{German CFC Legislation and the Cadbury-Schweppes Decision}

While in Germany resident individuals are taxed on their worldwide income, foreign dividends that are received by a German corporation are tax exempt. By default, a German corporation is also not taxable on earnings retained in a foreign subsidiary. ${ }^{5}$ Since 1972 , however, limits apply due to §§ 7-14 of the German Außensteuergesetz (German Foreign Tax Act). ${ }^{6}$ Under certain conditions, the German rules provide that the pro rata share of low-taxed passive income of a controlled foreign corporation (CFC) abroad is included in the shareholder's income on a current basis, implying that the exemption privilege is denied.

The German CFC rules provide that passive income is any income that does not fall into the active baskets as defined in $\S 8$ (1) Außensteuergesetz. The active baskets comprise income from agriculture, production, banking and insurance, trade, dividends, and the disposal of shares. Under certain requirements, also income from services, renting, and

\footnotetext{
${ }^{4}$ de la Fuente and Fuest (2010) provide a very insightful economic analysis of various ECJ rulings, but do not provide econometric evidence.

${ }^{5}$ Until 2000, the exemption was restricted to dividends repatriated from treaty countries. Since 2001, 95\% of the dividends are exempt in any case.

${ }^{6}$ For a detailed description see Förster and Schmidtmann (2004).
} 
leasing is deemed to be active. Income from borrowing and lending of capital is active if the German resident shareholder proves that all of the capital is raised in foreign capital markets from unrelated persons and the capital is lent to an active affiliated business or permanent establishment. Conversely, interest income from intra-group lending is passive if the lending is funded by equity provided by the German parent.

A German parent may be taxable on passive income earned by a foreign subsidiary if the income is subject to an effective tax rate of less than 25 percent (less than 30 percent before 2001). In addition, there is an ownership requirement for the applicability of the CFC rules: more than 50 percent of ordinary shares or voting rights in the foreign corporation must be held directly or indirectly by German resident individuals or companies. ${ }^{7}$ If a German parent is taxed on passive income of its foreign subsidiary, foreign taxes on the passive income can be credited against the German tax that derives from the CFC rules.

In a narrow legal sense, ECJ decisions apply to the relevant case only. In the CadburySchweppes case, the regulation that was challenged was a British one, not a German. This said, ECJ decisions have decisive influence on national courts confronted with similar cases. Moreover, as an immediate reaction to the Cadbury-Schweppes decision, the German Federal Ministry of Finance advised tax authorities to change application of the existing law. In a letter of 8 January 2007, tax authorities were instructed to suspend application of the CFC rules on passive income in the case of German owned subsidiaries in the EEA, subject to several conditions that should make sure that the foreign affiliate carries out active economic business with an employed workforce. A similar special clause for EEA subsidiaries was formally introduced in the foreign tax code by the tax reform act $2008{ }^{8}$

From the legal literature, it is not clear to which extent the Cadbury-Schweppes decision has increased tax avoidance opportunities for German multinationals. On the one hand, the decision has held that CFC rules imply an infringement of a fundamental freedom

\footnotetext{
${ }^{7}$ A reduced ownership requirement applies in the case of passive investment income. The German rules also apply to ownership chains, ruling out multi-tier structures as avoidance measures.

${ }^{8}$ Jahressteuergesetz 2008 (JStG 2008) of 20 December 2007.
} 
of the European treaties in all cases except those where the structure is wholly artificial and solely due to tax reasons. On the other hand, the concrete implementation into German law produces remaining uncertainties for firms as the tax authorities are allowed to ask for a proof that there is real economic activity going on in the foreign affiliate. This leaves some legal uncertainty for multinationals considering a low-tax country within the EEA to hold passive assets. The issue is essentially an empirical one.

\section{ECJ, CFC, and Passive Assets}

We use the MiDi database of the Deutsche Bundesbank to evaluate a possible impact of the Cadbury-Schweppes decision on the location of passive assets. German investors are legally required to report on their foreign subsidiary if it meets mild size and ownership requirements. The size requirement for wholly-owned foreign subsidiaries is a balance sheet total of more than $€ 3 \mathrm{~m}$. Reporting requirements include subsidiaries that are held via intermediate companies if ownership ties are sufficiently strong (see Lipponer 2003). Reported items include Germany’s foreign subsidiaries' lending to affiliated firms, equity ownership of affiliated companies, and financial assets in total. ${ }^{9}$ The data allows tracking of individual subsidiaries over time. Table 1 presents information on selected countries’ passive and active investment in 2005, i.e. before the Cadbury-Schweppes ruling in 2006, and data from year 2008 after the ruling. Countries are ordered by the total amount of passive investment received in 2005. ${ }^{10}$ Overall, the list of countries with large amounts of passive assets seems stable, but there are some exceptions like the Cayman Islands where passive assets shrank drastically from $€ 1.7 \mathrm{bn}$. to $€ 33 \mathrm{~m}$; in the case of Ireland the amount of passive assets more than doubled from 2005 to 2008 .

\footnotetext{
${ }^{9}$ This information is missing in most other company balance sheets as available in the Amadeus or Datastream data sets. Previous studies that use MiDi for analyzing tax effects on FDI include Ramb and Weichenrieder (2005), Büttner and Ruf (2007), or most recently, Ruf (2011).

${ }^{10}$ In order to correspond with the following regressions and the data presented in Ruf and Weichenrieder (2012) we censored firms at the 99.9 percentile of passive assets to calculate the country distributions.
} 
Table 1: Important host countries and passive investment (2005/2008, in million euro)

\begin{tabular}{|c|c|c|c|c|c|c|c|c|}
\hline & $\begin{array}{l}\text { Passive Assets } \\
2005\end{array}$ & $\begin{array}{l}\text { Fixed Assets and } \\
\text { Intangibles } 2005\end{array}$ & $\begin{array}{l}\text { \# Affiliates } \\
2005\end{array}$ & $\begin{array}{l}\text { Corporate } \\
\text { Tax Rate } \\
2005 \\
\end{array}$ & $\begin{array}{l}\text { Passive Assets } \\
2008\end{array}$ & $\begin{array}{l}\text { Fixed Assets and } \\
\text { Intangibles } 2008\end{array}$ & $\begin{array}{l}\text { \# Affiliates } \\
2008\end{array}$ & $\begin{array}{l}\text { Corporate } \\
\text { Tax Rate } \\
2008 \\
\end{array}$ \\
\hline USA & 5955 & 127849 & 968 & $40.0 \%$ & 4908 & 133367 & 1032 & $40.0 \%$ \\
\hline Netherlands & 4419 & 7392 & 561 & $31.5 \%$ & 3858 & 10650 & 612 & $25.5 \%$ \\
\hline UK & 1767 & 33915 & 702 & $30.0 \%$ & 1175 & 35612 & 716 & $28.0 \%$ \\
\hline Cayman Islands & 1691 & 66 & 10 & $0.0 \%$ & 33 & 280 & 15 & $0.0 \%$ \\
\hline France & 1606 & 15503 & 885 & $33.8 \%$ & 1626 & 19743 & 931 & $33.3 \%$ \\
\hline Luxembourg & 1525 & 4073 & 103 & $30.4 \%$ & 2760 & 5774 & 135 & $29.6 \%$ \\
\hline Austria & 1135 & 9674 & 623 & $25.0 \%$ & 830 & 11366 & 711 & $25.0 \%$ \\
\hline Australia & 965 & 2049 & 191 & $30.0 \%$ & 275 & 4400 & 203 & $30.0 \%$ \\
\hline Canada & 932 & 9424 & 220 & $36.1 \%$ & 705 & 3792 & 245 & $33.5 \%$ \\
\hline Italy & 900 & 12001 & 552 & $37.3 \%$ & 1367 & 14002 & 619 & $31.4 \%$ \\
\hline Russia & 879 & 2409 & 141 & $24.0 \%$ & 402 & 7370 & 240 & $24.0 \%$ \\
\hline Belgium & 726 & 5355 & 346 & $34.0 \%$ & 370 & 8346 & 405 & $34.0 \%$ \\
\hline South Africa & 612 & 1397 & 157 & $37.8 \%$ & 340 & 1266 & 157 & $34.6 \%$ \\
\hline Switzerland & 605 & 7023 & 533 & $21.3 \%$ & 820 & 11452 & 607 & $21.2 \%$ \\
\hline Japan & 564 & 3424 & 187 & $40.7 \%$ & 1223 & 3840 & 230 & $40.7 \%$ \\
\hline Spain & 457 & 10620 & 525 & $35.0 \%$ & 679 & 16554 & 550 & $30.0 \%$ \\
\hline Ireland & 385 & 1390 & 97 & $12.5 \%$ & 846 & 3038 & 105 & $12.5 \%$ \\
\hline Hong Kong & 383 & 408 & 166 & $17.5 \%$ & 461 & 612 & 200 & $16.5 \%$ \\
\hline Denmark & 344 & 1891 & 173 & $28.0 \%$ & 334 & 2815 & 205 & $25.0 \%$ \\
\hline
\end{tabular}

Note: The table reports the passive investment, defined as the total financial assets net of equity in affiliated firms and lending to affiliated firms, in the 20 countries that in 2005 had the largest passive investments. For confidentiality reasons, we left out one Caribbean country in which passive assets reduced from more than $€ 300 \mathrm{~m}$ in 2005 to $€ 0$ in 2008 . The calculations leave out firms with an ownership share of the German investor of less than 90\%, and exclude unincorporated subsidiaries and subsidiaries in banking and insurance, as these industries are treated differently under the German CFC rules. Fixed investment and intangibles are of nonfinancial companies. As in the following regressions, we censored firms at the 99.9 percentile of passive assets.

To identify the possible effects of the Cadbury-Schweppes ruling we decided to follow the setup used in Ruf and Weichenrieder (2012). This earlier contribution looks at the extent to which the German CFC rules restrict and influence the location of passive assets abroad, but looks at a shorter version of the data set, which disallows the evaluation of the ECJ ruling. The data used in the present paper stretches from 1999 to 2010 and after merging affiliates of the same German parent in the same host country contains 34,456 firm year observations. Table 2 describes the data more closely. During 1999 and 2010, 17\% of all observations were in countries for which the statutory tax rate is low enough to allow applicability of the German CFC rules and for these observations the variable CFC_DUMMY equals one. If 
CFC_DUMMY is one and the respective country is an EEA country, then we encoded the variable TREATMENT $=1$ (and zero otherwise) to label those EEA countries that due to their low taxes may be affected by the CFC rules. Comparison of the mean for CFC_DUMMY(.17) and TREATMENT (.08) reveal that roughly half of the firm year observations for which the CFC rules in principle were applicable due to a low tax rate in the host country where located in EEA countries that receive potentially preferential treatment since the ECJ decision (C-196/04). Finally, the dummy POST identifies years ending after the ECJ ruling. Our major interest will be in the resulting interaction variable TREATMENT*POST. A significantly positive value would support the view that the allocation of passive assets has been influenced by the fact that since Cadbury-Schweppes the German CFC rules are harder to apply in EEA countries. Our measurement of passive assets in this section is based on all financial assets less the equity holdings in affiliated companies and less the loans granted to affiliated companies. The later deduction is made since interest from those loans may be deemed active income if the subsidiary has raised the funds on local capital markets. Table 2 provides also summary evidence on the corporate tax rate, CT, the freedom of corruption, LN(CORR), the log of per capita income and of GDP, LN(GDPPC), LN(GDP) and the log of the local interest rate, LN(INTEREST). LN(ASSETS) measures fixed and intangible assets plus working capital of a subsidiary. 
Table 2: Descriptive statistics (1999-2010)

\begin{tabular}{lllllll}
\hline \hline & & & & & 5 th & 95 th \\
& Mean & Median & Std.dev. & Observations & percentile & percentile \\
\hline LN(PASSIVE ASSETS) & 4.98 & 4.82 & 2.82 & 36456 & 0.69 & 9.97 \\
CFC_DUMMY & 0.17 & 0.00 & 0.38 & 36456 & 0.00 & 1.00 \\
TREATMENT*POST & 0.05 & 0.00 & 0.22 & 36456 & 0.00 & 0.00 \\
TREATMENT & 0.08 & 0.00 & 0.28 & 36456 & 0.00 & 1.00 \\
POST & 0.43 & 0.00 & 0.49 & 36456 & 0.00 & 1.00 \\
CT & 0.31 & 0.33 & 0.07 & 36456 & 0.18 & 0.40 \\
LN(CORR) & 1.88 & 1.96 & 0.32 & 36456 & 1.25 & 2.22 \\
LN(GDPPC) & 10.18 & 10.31 & 0.49 & 36456 & 9.13 & 10.65 \\
LN(GDP) & 27.25 & 27.07 & 1.29 & 36456 & 25.70 & 30.05 \\
LN(INTEREST) & 1.79 & 1.73 & 0.53 & 36456 & 1.02 & 2.60 \\
LN(ASSETS) & 9.78 & 9.57 & 1.73 & 36456 & 7.75 & 12.88 \\
\hline \hline
\end{tabular}

Columns (1) to (4) of Table 3 report OLS estimations of the factors that affect the level of passive investment. The first specification in column (1) abstracts from the ECJ ruling and finds that the applicability of the German CFC rules (due to a sufficiently low tax in the host country) reduces the amount of passive investments in observed affiliates. After separately controlling for the corporate tax rate, which itself enters negatively, the applicability of the CFC rules reduces the amount of passive assets significantly. The coefficient of our dummy is 0.43 , which implies that the applicability of the CFC rules leads to an estimated reduction by some $35 \%$ using the approximation formula suggested by Kennedy (1981). The results are qualitatively very similar to those in Ruf and Weichenrieder (2012), which however comes up with a larger estimated coefficient of 0.77, implying a reduction by some $54 \%$. This difference should be due to the differences in the samples. While the years 2007-2010 have become available, the years 1996-1998 have been taken from the MiDi research files and were not included in the regressions of the present paper. Note that the significant reduction of the German corporate tax in 2008 should have reduced the incentives to keep passive assets abroad rather than in Germany. The German corporate tax rate including the average local tax was reduced from $38.4 \%$ in 2007 to $29.5 \%$ in 2008. 
The other variables also act as expected. The size of the affiliates' other assets, LN(ASSETS), increases the preferred amount of passive assets, the size and per capita income of the host economy enters positively, and so does freedom from corruption.

Columns (2) to (4) repeat the exercise, but now introduce the variables TREATMENT, POST and TREATMENT*POST. Depending on the introduction of different covariates we find that that the interaction term TREATMENT*POST is significant at the $10 \%$ or $5 \%$-level and has a positive sign. The results suggest that for low-tax countries within the EEA, like Ireland, Estonia, Latvia and Poland, the levels of passive assets have systematically increased compared to low-tax countries outside the EEA.

The OLS results presented in columns (1)-(4) may suffer from two problems. Using the logarithm of the stock of passive assets drops a large number of observations with zero passive assets and may lead to a possible selection bias. Estimating a logarithmic or semilogarithmic OLS model may also lead to biased estimations if the data is heteroskedastic (Silva and Tenreyo, 2006). For these reasons, many studies in international economics (e.g., Egger and Larch 2008) use a Poisson maximum-likelihood model, and this route has been taken also in the present paper. The results for the Poisson models are presented in columns (5)-(8) of Table 3, which otherwise contain the same set of regressors as the OLS models. The left-hand side in columns (5)-(8) is measured in total passive assets rather than its logarithm, but the tax coefficients, as in the previous columns, can be interpreted as semielasticities. In general, the point estimates for CFC_DUMMY and TREATMENT*POST are somewhat higher than in the OLS regressions. The opposite can be said for the local corporate tax, CT. The coefficient is still estimated as negative, but is now insignificant in all regressions. As in the OLS regressions, TREATMENT*POST is significant on the $10 \%$ or $5 \%$ levels depending on the set of covariates used. (Compared to the OLS regressions the index of financial freedom and the World Bank regulatory index gained in significance.) The Poisson models, similar to the OLS models, suggest a measurable effect of the ECJ ruling. 
Table 3: The allocation of passive assets

\begin{tabular}{|c|c|c|c|c|c|c|c|c|}
\hline & (1) & (2) & (3) & (4) & (5) & (6) & (7) & (8) \\
\hline CFC_DUMMY & $\begin{array}{l}-0.430^{* * *} \\
(0.13)\end{array}$ & $\begin{array}{l}-0.274^{* *} \\
(0.14)\end{array}$ & $\begin{array}{l}-0.302^{*} \\
(0.16)\end{array}$ & $\begin{array}{l}-0.275^{* *} \\
(0.13)\end{array}$ & $\begin{array}{l}-0.575^{* *} \\
(0.23)\end{array}$ & $\begin{array}{l}-0.647^{* *} \\
(0.28)\end{array}$ & $\begin{array}{l}-0.524 \\
(0.34)\end{array}$ & $\begin{array}{l}-0.429 \\
(0.28)\end{array}$ \\
\hline CT & $\begin{array}{l}-2.427^{* *} \\
(1.09)\end{array}$ & $\begin{array}{l}-2.593^{* *} \\
(1.09)\end{array}$ & $\begin{array}{l}-2.128 \\
(1.32)\end{array}$ & $\begin{array}{l}-2.547^{* *} \\
(1.18)\end{array}$ & $\begin{array}{l}-1.822 \\
(1.57)\end{array}$ & $\begin{array}{l}-1.939 \\
(1.59)\end{array}$ & $\begin{array}{l}-1.15 \\
(1.9)\end{array}$ & $\begin{array}{l}0.486 \\
(1.74)\end{array}$ \\
\hline \multicolumn{2}{|c|}{ TREATMENT *POST } & $\begin{array}{l}0.348^{*} \\
(0.18)\end{array}$ & $\begin{array}{l}0.396^{*} \\
(0.21)\end{array}$ & $\begin{array}{l}0.404^{* *} \\
(0.19)\end{array}$ & & $\begin{array}{l}0.672^{*} \\
(0.38)\end{array}$ & $\begin{array}{l}0.704^{* *} \\
(0.35)\end{array}$ & $\begin{array}{l}0.664 * \\
(0.39)\end{array}$ \\
\hline \multicolumn{2}{|l|}{ TREATMENT } & $\begin{array}{l}-0.559 * * * \\
(0.16)\end{array}$ & $\begin{array}{l}-0.572^{* * *} \\
(0.2)\end{array}$ & $\begin{array}{l}-0.589 * * * \\
(0.17)\end{array}$ & & $\begin{array}{l}-0.276 \\
(0.3)\end{array}$ & $\begin{array}{l}-0.575 \\
(0.38)\end{array}$ & $\begin{array}{l}-0.359 \\
(0.31)\end{array}$ \\
\hline POST & & $\begin{array}{l}-0.0304 \\
(0.2)\end{array}$ & $\begin{array}{l}0.0515 \\
(0.22)\end{array}$ & $\begin{array}{l}-0.0245 \\
(0.2)\end{array}$ & & $\begin{array}{l}0.0201 \\
(0.22)\end{array}$ & $\begin{array}{l}-0.15 \\
(0.19)\end{array}$ & $\begin{array}{l}0.054 \\
(0.22)\end{array}$ \\
\hline LN(ASSETS) & $\begin{array}{l}0.363 * * * \\
(0.018)\end{array}$ & $\begin{array}{l}0.363^{* * *} \\
(0.018)\end{array}$ & $\begin{array}{l}0.379 * * * \\
(0.02)\end{array}$ & $\begin{array}{l}0.361^{* * *} \\
(0.018)\end{array}$ & $\begin{array}{l}0.277^{* * *} \\
(0.03)\end{array}$ & $\begin{array}{l}0.275^{* * *} \\
(0.031)\end{array}$ & $\begin{array}{l}0.267 * * * \\
(0.033)\end{array}$ & $\begin{array}{l}0.266^{* * *} \\
(0.031)\end{array}$ \\
\hline LN(CORR) & $\begin{array}{l}0.708^{* * *} \\
(0.24)\end{array}$ & $\begin{array}{l}0.693^{* * *} \\
(0.23)\end{array}$ & $\begin{array}{l}0.912 * * * \\
(0.32)\end{array}$ & $\begin{array}{l}0.591 * \\
(0.32)\end{array}$ & $\begin{array}{l}0.109 \\
(0.3)\end{array}$ & $\begin{array}{l}0.12 \\
(0.29)\end{array}$ & $\begin{array}{l}0.116 \\
(0.36)\end{array}$ & $\begin{array}{l}-0.372^{*} \\
(0.22)\end{array}$ \\
\hline LN(GDPPC) & $\begin{array}{l}0.225^{*} \\
(0.13)\end{array}$ & $\begin{array}{l}0.213^{*} \\
(0.12)\end{array}$ & $\begin{array}{l}0.303^{*} \\
(0.17)\end{array}$ & $\begin{array}{l}0.165 \\
(0.11)\end{array}$ & $\begin{array}{l}1.188^{* * *} \\
(0.32)\end{array}$ & $\begin{array}{l}1.213^{* * *} \\
(0.33)\end{array}$ & $\begin{array}{l}1.200^{* * *} \\
(0.32)\end{array}$ & $\begin{array}{l}0.803^{* *} \\
(0.35)\end{array}$ \\
\hline LN(GDP) & $\begin{array}{l}0.113^{* *} \\
(0.051)\end{array}$ & $\begin{array}{l}0.114^{* *} \\
(0.05)\end{array}$ & $\begin{array}{l}0.0572 \\
(0.055)\end{array}$ & $\begin{array}{l}0.118^{* *} \\
(0.05)\end{array}$ & $\begin{array}{l}0.164 * \\
(0.094)\end{array}$ & $\begin{array}{l}0.167 * \\
(0.095)\end{array}$ & $\begin{array}{l}0.145 \\
(0.098)\end{array}$ & $\begin{array}{l}0.128 \\
(0.092)\end{array}$ \\
\hline LN(INTEREST) & $\begin{array}{l}-0.193^{* * *} \\
(0.072)\end{array}$ & $\begin{array}{l}-0.186^{* * *} \\
(0.071)\end{array}$ & & $\begin{array}{l}-0.168^{* *} \\
(0.07)\end{array}$ & $\begin{array}{l}0.158 \\
(0.11)\end{array}$ & $\begin{array}{l}0.159 \\
(0.11)\end{array}$ & & $\begin{array}{l}0.16 \\
(0.1)\end{array}$ \\
\hline \multicolumn{2}{|c|}{ LN(INFLATION) } & & $\begin{array}{l}0.044 \\
(0.053)\end{array}$ & & & & $\begin{array}{l}0.125^{*} \\
(0.071)\end{array}$ & \\
\hline \multicolumn{2}{|c|}{ LN(REAL-INTEREST) } & & $\begin{array}{l}0.0378 \\
(0.05)\end{array}$ & & & & $\begin{array}{l}-0.0689 \\
(0.072)\end{array}$ & \\
\hline \multicolumn{2}{|c|}{ HF FINANCIAL FREE } & & & $\begin{array}{l}0.003 \\
(0.0029)\end{array}$ & & & & $\begin{array}{l}0.00843^{* *} \\
(0.0037)\end{array}$ \\
\hline \multicolumn{2}{|c|}{ WB REGULATORY } & & & $\begin{array}{l}0.0599 \\
(0.21)\end{array}$ & & & & $\begin{array}{l}0.527^{* * *} \\
(0.19)\end{array}$ \\
\hline Observations & 36456 & 36456 & 31440 & 36241 & 113244 & 113244 & 94648 & 112093 \\
\hline R-squared & 0.55 & 0.55 & 0.56 & 0.55 & 0.75 & 0.75 & 0.78 & 0.75 \\
\hline
\end{tabular}

Notes: The dependent variable in (1)-(4) is the log of passive assets, in (5)-(8) the amount of passive assets. Standard errors in parentheses are corrected for clustering within country-year cells for columns (1)-(4) and robust for (5)-(8). Stars denote $p$-values; *** $p<0.01 ; * *<0.05 ; * p<0.1$. All estimations include time fixed effects and parent fixed effects, and firms are observed during the period 1999-2010 (unbalanced sample). Affiliates in banking and insurance are not included in the sample, since their activities are assumed to be active according to the German CFC rules. In cases in which a German parent owns more than one subsidiary in a specific country, we aggregated passive investment across country-year observations. The data has been censored at 0.1 percent of the observations with the largest amounts of passive assets. For the Poisson estimates we use the term $1-(\log \operatorname{likelihood} / \log$ likelihood of the Poisson model with only a constant term) as the pseudo R2 (see Greene 2008, 908-9). 
Table 4: The allocation of affiliates with passive assets

\begin{tabular}{|c|c|c|c|c|c|c|c|c|}
\hline & (1) & $(2)$ & (3) & (4) & (5) & (6) & (7) & (8) \\
\hline \multirow[t]{2}{*}{ CFC_DUMMY } & 0.136 & 0.169 & 0.2 & $0.309 * *$ & 0.00522 & $0.00843^{* *}$ & $0.0121^{* *}$ & $0.0100 * *$ \\
\hline & $(0.11)$ & $(0.13)$ & $(0.14)$ & $(0.13)$ & $(0.0033)$ & $(0.0043)$ & $(0.0051)$ & $(0.0041)$ \\
\hline \multirow[t]{2}{*}{$\mathrm{CT}$} & $-1.347 * * *$ & $-1.330 * * *$ & $-1.299 * * *$ & 0.454 & 0.0195 & 0.0224 & 0.0251 & $0.0431^{* * *}$ \\
\hline & $(0.41)$ & $(0.42)$ & $(0.45)$ & $(0.5)$ & $(0.016)$ & $(0.016)$ & $(0.019)$ & $(0.015)$ \\
\hline \multirow[t]{2}{*}{ TREAT*TREATPERIOD } & & $0.267 *$ & $0.477 * * *$ & 0.134 & & 0.000198 & 0.00171 & -0.00107 \\
\hline & & $(0.15)$ & $(0.16)$ & $(0.15)$ & & $(0.0027)$ & $(0.003)$ & $(0.0027)$ \\
\hline \multirow[t]{2}{*}{ TREAT } & & -0.234 & -0.273 & $-0.309 * *$ & & $-0.00592 *$ & $-0.00898 * *$ & $-0.00907 * * *$ \\
\hline & & $(0.14)$ & $(0.17)$ & $(0.14)$ & & $(0.0032)$ & $(0.0039)$ & $(0.0031)$ \\
\hline \multirow[t]{2}{*}{ TREATPERIOD } & & $-0.249 * * *$ & -0.158 & -0.145 & & -0.00236 & -0.000738 & -0.000787 \\
\hline & & $(0.089)$ & $(0.097)$ & $(0.091)$ & & $(0.0048)$ & $(0.0056)$ & $(0.0049)$ \\
\hline \multirow[t]{2}{*}{ LN(CORR) } & $0.736 * * *$ & $0.737 * * *$ & $0.517 * * *$ & -0.199 & $0.0150 * * *$ & $0.0147 * * *$ & $0.0141 * * *$ & 0.00156 \\
\hline & $(0.13)$ & $(0.12)$ & $(0.13)$ & $(0.15)$ & $(0.0032)$ & $(0.0032)$ & $(0.0041)$ & $(0.0041)$ \\
\hline \multirow[t]{2}{*}{ LN(GDPPC) } & $0.840 * * *$ & $0.836 * * *$ & $0.909 * * *$ & $0.604 * * *$ & $0.00747 * * *$ & $0.00751^{* * *}$ & $0.00816^{* * *}$ & $0.00433 * * *$ \\
\hline & $(0.081)$ & $(0.082)$ & $(0.097)$ & $(0.088)$ & $(0.0016)$ & $(0.0016)$ & $(0.0021)$ & $(0.0014)$ \\
\hline \multirow[t]{2}{*}{ LN(GDP) } & $0.485^{* * *}$ & $0.483 * * *$ & $0.485^{* * *}$ & $0.438 * * *$ & $0.00810^{* * *}$ & $0.00799 * * *$ & $0.00880^{* * *}$ & $0.00796^{* * *}$ \\
\hline & $(0.025)$ & $(0.025)$ & $(0.026)$ & $(0.025)$ & $(0.00074)$ & $(0.00074)$ & $(0.00083)$ & $(0.0007)$ \\
\hline \multirow[t]{2}{*}{ LN(INTEREST) } & $-0.0943 *$ & $-0.0995^{*}$ & & $-0.142 * *$ & $-0.00339 * *$ & $-0.00366 * *$ & & $-0.00414 * * *$ \\
\hline & $(0.052)$ & $(0.053)$ & & $(0.056)$ & $(0.0015)$ & $(0.0015)$ & & $(0.0015)$ \\
\hline \multirow[t]{2}{*}{ HF FINANCIAL FREE } & & & & $0.00789 * * *$ & & & & $0.000366^{* * *}$ \\
\hline & & & & $(0.0022)$ & & & & $(0.000065)$ \\
\hline \multirow[t]{2}{*}{ WB REGULATORY } & & & & $0.627 * * *$ & & & & $0.00520 * *$ \\
\hline & & & & $(0.097)$ & & & & $(0.0026)$ \\
\hline \multirow[t]{2}{*}{ LN(INFLATION) } & & & $-0.142 * * *$ & & & & $-0.00202 *$ & \\
\hline & & & $(0.027)$ & & & & $(0.0011)$ & \\
\hline \multirow[t]{2}{*}{ LN(REAL-INTEREST) } & & & $-0.0957 * * *$ & & & & -0.00141 & \\
\hline & & & $(0.037)$ & & & & (0.00099) & \\
\hline Observations & 233067 & 233067 & 180143 & 229088 & 235385 & 235385 & 191821 & 231616 \\
\hline
\end{tabular}

Notes: The dependent variable is one if a parent holds an affiliate with passive assets exceeding ten percent of total assets in the respective country and year country and zero otherwise (including cases with no affiliate in this country at all). Columns (1)-(4) report conditional logit estimates with parent fixed effects. Columns (1)-(4) represent coefficients rather than odds ratios. Standard errors are corrected for clustering at the parent level. Columns (5)-(8) report on linear probability models using OLS with standard errors clustered across country-year cells. Stars denote $p$-values: ${ }^{* * *} p<0.01$; $* * p<0.05$; ${ }^{*} p<0.1$. All estimations include parent fixed effects, and firms are observed during the period 1999-2010 (unbalanced sample). Affiliates in banking and insurance are not considered in the sample, since their activities are assumed to be active according to the German CFC rules. 
The Poisson estimates in Table 3 solve the problem that derives from observations with zero passive assets, but they are based on existing subsidiaries only. Some affiliates may not exist because of the local tax system or the applicability of the CFC rules. As an additional exercise we therefore look at the problem of a German parent that determines to locate affiliates with sizable passive assets. We define for each parent, country and year an endogenous binary variable. It takes on the value one if the parent under consideration owns an affiliate with a substantial fraction of passive assets in a country, and zero otherwise. The German CFC rules may allow having ten percent of income from passive investment if the total income from that source does not exceed a certain absolute limit. This led us to use a ten percent rule for encoding. ${ }^{11}$ If passive assets exceed ten percent of total assets, then observations receive the value one.

Table 4 reports on conditional logit models [columns (1)-(4)] and linear probability models [columns (5)-(8)] to investigate the issue. The models include the country characteristics used in Table 3. GDP, GDP per capita, and the corruption index perform in the expected positive way. Unlike in Table 3, the interest level now enters significantly negative.

In one important respect, the results draw a different picture of the effects of the German CFC rules than the results in Table 3: CFC_DUMMY is insignificant in 5 out of the 8 regressions and though significant in the other three regressions it unexpectedly has a positive coefficient. CT has a mostly significant and negative coefficient in the logit models, but a positive and mostly insignificant coefficient in the linear probability models. The variable that tests the differential effect of the ECJ ruling on low-tax EEA and low-tax nonEEA countries again is TREAT*TREATPERIOD. It is positive in five out of four columns and more significantly so in the logit models. Taken together, the results suggest only weak evidence that the ECJ decision affected the location of firms with large fractions of passive investment. The result may be influenced by the fact that some post Cadbury-Schweppes

\footnotetext{
${ }^{11}$ Again, this follows Ruf and Weichenrieder (2012) who do not comment on the ECJ ruling.
} 
ruling years are crisis years with a reduced activity of new FDI firms and many German multinationals concerned about how to digest losses rather than how to avoid taxes.

\section{Summary and Conclusions}

The extent to which the Cadbury-Schweppes decision of the ECJ has changed the possibilities to curb the outflow of passive investment has been a topic of considerable speculation, but so far of no systematic evidence. The present paper looks at the development of passive investment in EU/EEA versus non-EEA countries to gauge the empirical relevance of the decision for German multinationals. While the evidence for a change in the sheer number of affiliates with significant passive assets is weak, the paper provides evidence that the passive investments in low-tax EEA countries have increased compared to low-tax non-EEA countries. Aggregate figures suggest that the relative increase of passive investment in EEA countries is accompanied by a reduction in the passive investments in non-EEA countries. While, for example, our measure of German passive investment in Ireland has more than doubled from 2005 to 2008, the absolute level of passive investment in that year (€846m) does not look like a major threat to German tax revenues. As a caveat, this is not implying that completely scrapping CFC legislation in the EEA would be innocuous as the current rules, despite the ECJ decision, can prevent wholly artificial structures without economic content. 


\section{Bibliograpy}

Altshuler, R., and G. Hubbard (2003) "The effect of the tax reform act of 1986 on the location of assets in financial services firms“, Journal of Public Economics 87, 109127.

Barry, F., and R. Healy-Rae (2010) "FDI implications of recent European Court of Justice decisions on corporation tax matters", European Business Organization Law Review 11, 125-146.

Büttner, T., and M. Ruf (2007) "Tax Incentives and the location of FDI: Evidence from a panel of German multinationals”, International Tax and Public Finance 14, 151-164.

Egger, P., and M. Larch (2008) "Interdependent preferential trade agreement memberships: an empirical analysis”, Journal of International Economics 76, 384-399.

Förster, D., and G. Schmidtmann (2004) “CFC legislation in Germany”, Intertax 476-486.

Greene, W.H. (2008) Econometric Analysis, 6th ed. (Upper Saddle River: Pearson Prentice Hall).

Kennedy, P.E. (1981) "Estimation with correctly interpreted dummy variables in semilogarithmic equations”, American Economic Review 71, 801.

Lipponer, A. (2003) „Deutsche Bundesbank’s FDI micro database“, Schmollers Jahrbuch Zeitschrift für Wirtschafts- und Sozialwissenschaften 123, 593-600.

Ramb, F., and A.J. Weichenrieder (2005) "Taxes and the financial structure of German inbound FDI”, Review of World Economics 141, 670-692.

Ruf, M. (2011) "Why is the response of multinationals' capital-structure choice to tax incentives that low? Some possible explanations”, FinanzArchiv/Public Finance Analysis 67, 123-144.

Ruf, M., and A.J. Weichenrieder (2012) “The taxation of passive foreign investment- Lessons from German experience", Canadian Journal of Economics 45, 1504-1528.

OECD (2013) Action Plan on Base Erosion and Profit Shifting, OECD Publishing. http://dx.doi.org/10.1787/9789264202719-en.

Santos Silva, J.M.C., and S. Tenreyro (2006), “The log of gravity”, Review of Economics and Statistics 88, 641-658.

Weichenrieder, A.J. (1996) "Anti-tax-avoidance provisions and the size of foreign direct investment“, International Tax and Public Finance 3, 67-81.

Weichenrieder, A.J. (2005) “(Why) Do we need corporate taxation?”, Proceedings of OeNB Workshops No.6 - Capital Taxation after EU Enlargement, 60-72.

Egger, P., and G. Wamser (2011), The impact of controlled foreign company legislation on real investments abroad: a two-dimensional regression discontinuity design, CEPR Discussion Paper No. 8460. 